\title{
A Campus-Wide Community-Engaged Learning Study: Insights and Future Directions
}

\author{
Darren E. Lund, Bronwyn Bragg
}

\begin{abstract}
AвSTRACt The authors undertook a campus-wide scan of community-engaged learning (CEL) initiatives at a large University. With collaboration from staff and leadership of the campus Centre For Community-Engaged Learning, the researchers designed an open-ended qualitative interview and questionnaire for senior administrators and faculty leaders across all local undergraduate faculties. Guiding questions for this project included: How do the various faculties and schools within the university define their relationship with community? What activities are considered CEL? How do students engage in these activities? What are the benefits of engaging with community? From these came specific interview questions that were administered to senior administration from each faculty, and further interviews were sought with identified faculty leaders. Findings are listed by faculty, with examples and definitions, and a concluding section offers insights and discussion around strategies to strengthen and enhance CEL.
\end{abstract}

KEYWords community-engaged learning, undergraduate education, university-community relations, service-learning

Increasingly, interaction and engagement between universities and the communities where they are situated are critical factors of success for both parties. Collaboration between these two partners can lead to a myriad of opportunities for both university and community-stakeholders; students gain hands-on experience through co-op and internship placements, researchers develop powerful insights working in collaboration with community partners, employers and business partners build relationships with potential employees, universities attract students seeking community-engaged learning, and a dialogue is opened that bridges the gap between higher education and "the real world." For the past few decades, service-learning has played a large part in this community engagement by fostering student experiences that benefit the community in reciprocal ways (Butin, 2010; Hatcher \& Bringle, 2012; Tinkler \& Tinkler, 2017).

Understanding the critical role that community partners play in universities' success, the university's Strategic Direction for 2011-2016 (University of Calgary, 2011) set a goal to "fully integrate the university with the community." This article focuses on a selection of findings from a larger internal environmental scan of one slice of community-university interaction, namely, on community-engaged learning opportunities for undergraduate students at the University of Calgary (Bragg \& Lund, 2015). Past studies of the impact of organizational 
decisions have typically focused on student perspectives (e.g., Armitage \& Levac, 2015; De Leon, 2014; Moely \& Ilustre, 2014; Przednowek et al., 2018) or faculty perspectives (e.g., Cooper, 2014; O’Meara et al., 2013). Drawing on university administrators and program directors' engagement, this research seeks to provide an overlooked perspective in communityengaged learning (CEL) planning and programming.

CEL can be any form of interaction with the community at large beyond the academic institution while students pursue their higher education; ultimately, the focus for CEL is the enhancement of the student experience, and the connection of the student experience with community leaders and salient issues in the community (Cooper, 2014). At the time the research was conducted there was no common definition or universally shared understanding of what CEL entails at this university, nor a comprehensive documenting of the extent to which students are engaged in these activities. Some typical features of research on CEL at universities include the lack of precise methods to evaluate these programs and a dearth of the perspectives of program administrators; as O'Meara et al., (2013) noted, "future studies might interview community-engaged faculty with their organizational leaders and colleagues to understand how such actions were interpreted and understood from multiple vantage points" (p. 17) this research is a step in that direction.

CEL and service-learning are increasingly recognized as "high impact practices" that can be transformative for students who participate. The National Survey of Student Engagement (NSSE) found that high-impact practices "demand considerable time and effort, provide learning opportunities outside of the classroom, require meaningful interactions with faculty and students, encourage interaction with diverse others, and provide frequent and meaningful feedback. Participation in these practices can be life-changing" (NSSE, 2013, p. 1).

As "high impact" activities, these opportunities contribute to students' satisfaction with their university experience and are associated with greater student success. Many of these activities are also associated with increased community involvement following graduation, career preparation, leadership development, critical thinking, and the ability to apply learning in different settings.

\section{Project Background and Guiding Questions}

In 2014, staff from the Centre for Community-Engaged Learning (CCEL) met with the university's Vice Provosts of Teaching and Learning, and Student Experience to discuss a need to increase significantly the number of students participating in community-learning opportunities, and to creating clear pathways to community involvement for students. Guiding questions included: How do the various faculties and schools within the university define their relationship with community? What activities are considered CEL? How do students engage in these activities? What are the benefits of engaging with community?

The CCEL then invited the lead author to plan and conduct a CEL baseline environmental scan across the University. This was not for any accreditation purposes but to understand better the context of CEL in various faculties from multiple perspectives. A goal of this research was to capture the diversity of learning experiences held under the term "community-engaged 
learning" and the ways that different schools and faculties across the university were taking up this concept at the time. In the following section, we describe the definition of terms and approach employed to capture these findings, followed by the results by faculty, and a section that highlights key learnings and conclusions.

\section{Definition of Terms}

Because of the expansive nature of the term "community-engaged learning," there was a need to define key terms based on current relevant literature and with the cooperation of the CCEL; this research focused exclusively on CEL opportunities for undergraduate students only. The definition below excludes other forms of university-community partnerships such as community-based research or community-engaged scholarship which tend not to include a specific student-focused learning component:

Community-Engaged Learning CEL can be any form of interaction with the community at large beyond the academic institution while students pursues their higher education. CEL includes both curricular and co-curricular engagements such as internships, practica, capstone courses, volunteerism, and/or service-learning opportunities. In this sense, we understand CEL to be an encompassing "umbrella" term for community-university interactions. CEL has two key components: a) students are engaged directly in some form with a community; and b) students engage in activities explicitly related to their learning.

Community Service-Learning Service-learning differs from other forms of experiential learning and volunteerism in that the benefits of a partnership are shared equally between the service provider and the recipient of service, and the focus of the project is equally student learning and community benefit. Reflection, reciprocity, and relationships are the core of successful service-learning programs.

Experiential Learning Experiential learning and CEL often go hand-in-hand. While a fulsome discussion of experiential learning goes beyond the scope of this scan, generally, experiential learning is thought of as more hands-on, process-oriented learning:

Unlike traditional classroom situations where students may compete with one another or remain uninvolved or unmotivated and where the instruction is highly structured, students in experiential learning situations cooperate and learn from one another in a more semi-structured approach... to engage students in direct experiences... tied to real world problems. (National Illinois University, 2012)

Through experiential learning, students are expected to take a more active role in their learning experiences. Reflection, critical analysis, and synthesis are all key components of an experiential learning environment. 
Capstone \& Co-op Programs Co-operative components or "co-ops" are professional work experiences linked to the student's academic work. Placements are often structured to meet students' educational and career goals. Co-op experience is usually included on a student's transcript in addition to designated credit hours awarded for its completion; these experiences can be for credit, not for credit, paid, or unpaid.

Practica Practica is often a required component of studying and placing students in supervised professional settings. Students develop competencies and apply previously studied theory and content. Practicum experiences also allow students to design and develop a project in which they use knowledge and develop skills.

Volunteering Volunteering is generally considered a less formal way for students to engage with the broader community, either individually or as part of a group. Volunteer experiences can take place as one-off engagements or be structured for more regular or continuous involvement. These experiences may be organized by campus clubs or student groups, and may take place on or off campus.

The focus of this research is primarily on curricular engagements, in order to provide a baseline to inform future curricular directions both within and across disciplines. We interviewed senior administrators in each faculty as well as faculty leaders in this area. Our approach focused more on the curricular engagements within the faculty - practica, co-ops, and service-learning - and less on the co-curricular involvement of students within each faculty, addressed more briefly in a final section.

\section{Methodology}

The research proceeded in three stages. First, the authors and staff from the Centre for Community-Engaged Learning met to define terms, narrow the scope of the research, and develop a strategy for conducting the research. The team also mapped out the various faculties and schools across campus that would be included. Ethical approval was obtained for the agreed approach. Second, the researchers reached out to the Associate Deans of Teaching and Learning, where applicable, or other administrators across all local undergraduate faculties. Where no such position existed, the team spoke with the Associate Dean Academic and, in some cases, the Dean of the School or faculty. The administrators were invited to participate either in an in-person interview or complete a brief questionnaire about CEL within the faculty or school, following the usual protocols of qualitative, open-ended interviewing (Creswell, 2013). Interviewees were told their responses would be anonymized but that there could be no guarantee of absolute anonymity.

The researchers spoke to 9 out of 11 faculty administrators in person and received questionnaire responses from the remaining two. The questionnaire contained the following five questions:

Engaged Scholar Journal: Community-Engaged Research, Teaching, and Learning 
1. Does your faculty have a working definition for community-engaged learning? If yes, how is community-engaged learning defined within the faculty?

2. Please provide an example or examples of community-engaged learning initiatives or activities within the faculty.

3. Does your faculty currently measure, evaluate, or collect data about community-engaged learning initiatives within the faculty? (i.e., the impact on students' learning outcomes, student experience, etc.)

4. Can you identify a key leader or key leaders within the faculty regarding community-engaged learning? (Please note that we will be reaching out to these faculty members for participation in our study)

5. Do you have other comments about community-engaged learning within your faculty?

The third stage of the research involved reaching out to key faculty leaders within each faculty, identified by administrators as involved in a CEL initiative within the faculty. This research draws on interviews with 13 faculty members or staff from across local undergraduate faculties. To capture the co-curricular CEL initiatives, we interviewed a senior administrator of student experience and collected data from the Centre for Community-Engaged Learning.

\section{Findings}

The following proceeds faculty by faculty across the university, listed in alphabetical order. Each section defines CEL within the faculty as relevant, followed by examples. Other comments about CEL from administrators, faculty, and staff are included throughout. The final section describes co-curricular forms of CEL.

\section{Cumming School of Medicine}

This scan focused on the Doctor of Medicine (MD) program within the Cumming School of Medicine as it is considered an undergraduate program, and we spoke with a senior administrator. Within the MD program, CEL is tied to accreditation standards for medical schools in Canada. In particular, standard 6.6 refers to "service-learning." The accreditation standard reads: "The faculty of a medical school ensure that the medical education program provides sufficient opportunities for, encourages, and supports medical student participation in service-learning and community service activities." This accreditation standard informs the school's thinking around CEL more broadly.

One example of a mandatory CEL program is the Population Health Course. All MD students take this course within their first two years of the program. The focus is on working with vulnerable communities. These communities might include people with disabilities, immigrant/refugee populations, Indigenous health, families of children with disabilities, homelessness and addiction, and the elderly. Students work in pairs to visit community members and complete an ethnographic interview. The results of the interview are shared with 
other members of the group working with that population. A research project is developed from the collection interviews. A Master Teacher for the class described it as a "communitybased critical inquiry," explaining it as follows:

It's important because it's what physicians are supposed to do. As clinicians, we need to be community-engaged because we deal with individuals all the time. But individuals come out of a population, so what goes on in their world hugely informs both why they're there in the first place, and what can we do to intervene or help if they need our intervention or help. I think to be an effective clinician you need to be willing to understand the world in which your patients live. (PM1, 03.14.2015)

Some other examples of CEL in the School include a voluntary Global Health concentration and a voluntary Global Health/Remote Community elective. There are challenges involved in delivering CEL within a three-year medical program. Upon entrance to the program, medical students have to make crucial decisions quickly about their training, including picking their residency placement. This administrator acknowledged that as a faculty, there is room to grow in the area of CEL. The goal for the medical school is that, within five years, all students in the program will experience CEL opportunities. Like representatives from other faculties and schools we spoke to, the faculty administrator stated that having more CEL opportunities would likely increase the diversity of the student population, an ongoing goal with the medical school.

\section{Faculty of Arts}

The Faculty of Arts does not currently have a formal definition of CEL. It does, however, show up in several different ways throughout the faculty. We spoke to an Instructor in the Department of Communication, Media, and Film, and a Co-op Education Coordinator in the faculty about the various forms of CEL within the faculty.

One example of CEL is the Co-op Program in Arts, in which students from the Faculty of Arts participate in co-op placements working in the not-for-profit, private, and public sectors. In these opportunities, students engage in various ways with the community. For example, an International Relations student worked three terms back-to-back (12 months long) at a local energy company in its Community Consultation and Regulatory Affairs. Her role was working with a senior Indigenous Relations Advisor ensuring timely consultation activities concerning energy exploration projects. She liaised with community and business stakeholders to maintain relations, accurate information, and managing reporting requirements. She also helped collect and report statistical information regarding its involvement in Indigenous communities, including community investment and industry agreements.

The co-op program evaluates students' learning goals and progress at mid-term through a site visit and at end-of-term with a reflective report that follows a rubric, an updated résumé, program and term evaluation form, and an employer assessment. Students receive a Pass/Fail 
on the co-op work term experience and three terms leads to a designation on their degree. Other examples of CEL include a Service-Learning course in the Faculty of Arts, a Travel Study program, and Curricular Peer Mentorship. As an instructor in the faculty expressed it, CEL:

gets the students out of their heads... Universities need to help students grow, help develop citizenship. To have a good society you need well-informed citizens who can make decisions for the general common good, and I think getting students outside of classrooms allows them to experience what that looks like. (PA2, 01.20.2015)

\section{Faculty of Law}

The Faculty of Law does not currently have a working definition of CEL. One example of community engagement is a business ventures clinic. This a unique partnership between the Faculty of Law and local law firms. The clinic is designed to offer start-up businesses access to pro bono legal assistance while also giving law students the chance to put their education into practice within the local business community. Third-year law students work with entrepreneurs and start-up business owners. Students are partnered with a practicing corporate-commercial lawyer as a mentor. They get hands-on experience drafting various legal documents and providing information on legal questions that might arise in entrepreneurial companies, such as corporate governance considerations, business structures, and intellectual property issues.

Other examples within the faculty include judge shadowing programs and clerkship opportunities for students with the court, a student mooting program, a mentorship program for law students run through the national bar association, and many legal clinics, including student legal assistance, pro bono students, a constitutional law clinic, a business ventures clinic, and an environmental law clinic in which law students provide legal services to clients. In each case, they are supervised by practicing lawyers.

\section{Faculty of Kinesiology}

While the Faulty of Kinesiology has no formal definition of CEL, a senior administrator reflected that the faculty is engaged in a variety of ways with some diverse communities, saying:

I would take [CEL] broadly to say that it is any academic learning that goes on beyond our classrooms. And so, the community for us could even be within our building because we have athletics and we have things like the Olympic Oval and the Sports Medicine Centre, as well as the larger community out there, so we have many activities from an undergraduate perspective that are involving all of those areas. (PK1, 01.22.2015)

Other examples of CEL include a practicum course for which students are interviewed by a potential placement and are selected for practicum placement. Students work in these placements 5-6 hours per week. It is equivalent to one senior kinesiology course. It is a pass/ 
fail course with no class-based component. Students complete a total of 60-72 hours total within the term. Likewise, the Work Term is similar to practicum but equivalent to five senior Kinesiology options (5 half-course equivalents). Students work 35-40 hours/week for the entire term. Some of their placements have included comprehensive healthcare clinics, health promotion (i.e., Kids Cancer Care, Heart and Stroke Foundation, Canadian Liver Foundation), Alex Community Health, Pathways to Housing, Canadian Sport Institute, Running Injury Clinic, Southern Alberta Renal Program, cancer survivors (exploring the impact of exercise on cancer survivors and those newly diagnosed), Calgary Fire Department, and the Centre for Video Analysis.

Another program sends kinesiology students to work in the schools and undertakes initiatives with children in schools. Also, athletic therapy students work with varsity athletic teams as trainers for the teams. Some students work with people with disabilities who attend recreation programs, and students learning to be personal trainers will partner with campus security to design a training plan to complete an assessment. Senior administrators explained CEL in their faculty as follows:

I think our faculty is heavily involved in the community in so many ways. Between athletics and active living, we have over two million people use this facility...that's a community-engagement piece, not from an academic perspective necessarily, but that's part of our faculty. (PK2, 01.24.2015)

The administrator also pointed out that "It is important to reflect on how community engagement is measured and evaluated, as well as how community engagement is linked to professor evaluations" (PK2, 01.24.2015).

\section{Faculty of Nursing}

Two senior administrators and a faculty leader participated in an interview for this project. The latter reflected that "notions of community are fairly well embedded in nursing as a discipline" (PN1, 01.14.2015). Indeed, nursing is on the forefront of practice that is informed through cultural humility (see Abdul-Raheem, 2018). While the faculty does not have a formal definition, there are numerous examples of CEL. For this study, the administrators limited their conception of CEL to "work in the broader community" beyond the hospital and traditional clinical settings.

The primary example of CEL in this faculty takes place in students' third term. Students work in groups of eight, collaborate with communities to identify an issue, develop an intervention, and then evaluate their work. Both administrators and the faculty leader discussed the collaborative nature of the strong partnerships between the faculty and the community. The faculty attempts to support community needs and initiatives and the current work, as a faculty leader explains: 
We have shifted now to point where we have so many people who want to work with us that we do not have enough students to meet the need and I think what's happened... is, it's not only just meeting our students' learning needs, it's actually meeting needs for the community members and that community partner. (PN2, 02.17.2015)

Students participate in 19 hours of "clinical practice" per week: 12 hours are off-campus, focused work with the community, and the other seven hours are "on-campus practice." This provides a space for "students to talk about and unpack that experiential learning and try to connect that to a theoretical understanding" (PN2, 02.17.2015). Some community programs that have collaborated in the past include Boys and Girls Club, various schools and preschools, programs for homeless youth, the Calgary Immigrant Women's Association, programs for low-income seniors living downtown, the Alzheimer's Society, and the Ogden Community Association.

According to the faculty member, the amount of time and effort involved in developing CEL "isn't necessarily always recognized" (PN2, 02.17.2015). This is a problem not just within the Faculty of Nursing but across the university and academia more broadly. How official university processes evaluate faculty do not necessarily match with creating and honouring the efforts that go into creating rich CEL experiences. A faculty member expressed that "we need to have some sort of visionary idea of what good academic conduct, performance looks like in order to make CEL fit, or otherwise we're talking about square pegs in round holes" (PN3, 02.24.2015).

\section{Faculty of Science}

The Faculty of Science does not have a working definition of CEL, and according to a senior administrator, "It is not a term that's commonly used in our everyday conversations about teaching and learning" (PS1, 01.15.2015). CEL is generally conceptualized in the faculty as situations where instructors go out into the community and share their work or present their work in the community.

There are "small pockets" within the interdisciplinary programs, in particular within environmental science. An example of CEL within the Faculty of Science is the fourth-year capstone course in Environmental Science, a mandatory course that approximately 40 students complete per year. The course revolves around "real world" problems and engages with research questions derived from community interests, questions, or concerns. One of the instructors for the course reported focusing it around issues related to water quality. For example, students might explore questions about sewage in the Bow River or stormwater ponds' efficacy. The class of 40 works in smaller groups on particular questions of interest. The project involves collecting samples, analyzing data, synthesizing results, and presenting findings to the community; it also requires that students work in groups and develop their communication and teamwork skills.

This faculty member noted that the course has a strong reputation in the community and, often, possible projects are brought to the university for the students to engage with. 
The benefit of the student research, according to the faculty member, is two-way, both for the students and communities:

We can ask really controversial and difficult questions and we don't have a stake. So we can talk about something like sewage in the Bow River... or we talk about First Nations problems... but we're not on one side or the other side. We have a unique, objective position and we can contribute in a unique way. That is really important, I think. (PS2, 03.30.2015)

Further, an administrator talked about the potential for how CEL initiatives might grow in the faculty in the coming years:

I think science lends itself to community-engaged learning more than we think it does... I think people are interested in science, I think they have questions about the natural world, and I think this would a tremendous way for us to engage with First Nations communities, but I think we are a ways out from... moving that forward as a priority in the faculty. (PS1, 01.15.2015)

This administrator also suggested that increasing opportunities for CEL might lead to greater diversity in recruiting and retaining women in science.

\section{Faculty of Social Work}

According to a senior administrator of the Faculty of Social Work, CEL is foundational to all students' and instructors' work. It is considered a "signature pedagogy" within the faculty. As an applied profession, students spend hundreds of hours working in community settings to become social workers. The senior administrator explained:

It's part of our value set and philosophy as a profession... But it's also a conscious choice on our part so we have a strategic plan in place, and it's one of our three pillars; we say simply that our community will be part of us and we will be part of our community. It should then be reflected in everything we do. (PSW1, 03.14.2015)

There are several specific examples of CEL, including through their Field Education components. As part of any Social Work degree program, students must complete two field placements. These placements are regulated by professional standards and must be supervised by a practicing social work professional, and they take place in a variety of community settings. Students also spend a portion of this time in a classroom setting with faculty to debrief and reflect on their learning experiences.

Community leaders regularly work as sessional instructors in the faculty and are often involved on faculty and student committees. The faculty also has Research Chairs based in 
the community. For example, at Wood's Homes, this faculty member will divide work time between the community and the university.

Further, many community-based initiatives are examples of collaborative research and practice. One Social Work faculty member is leading a comprehensive identity-based community intervention project. The project involves a wide range of key community stakeholders, including both Public and Separate School Boards, the Calgary Police Service, and many immigrant-serving agencies and other not-for-profit organizations. Its goal is to deliver a program that is both practice- and research-based with the intention of diverting atrisk immigrant youth away from gang involvement. Opportunities for student involvement include practicum placements and field education.

A faculty member offered a reminder of how community engagement is tied to professor evaluations, advancement, and promotion:

I will say that the days when I could write a paper, and have it published, and have it read by fifty of my best academic friends and getting a reward for that, those days should be over, I think. It takes the whole conversation about where research comes from, how we disseminate knowledge, how we apply knowledge, how we shape our classrooms and engage community members in thinking about learning experiences. All of our traditional reward mechanisms and expectation have to change if we want to get any real traction. (PSW2, 03.25.2015)

\section{Faculty of Veterinary Medicine}

Within Veterinary Medicine, CEL is conceptualized as having two aspects: a) students work or engage in activities in the community outside the university's confines (including servicelearning opportunities), and b) community members are brought to campus to engage with students in the faculty.

The Faculty of Veterinary Medicine differs from other veterinary medicine programs across the country. Typically, programs have an on-campus training hospital, but this is not the case in Calgary. Instead, students spend most of their last (fourth) year of the program off-campus and working in the community. The fourth year is forty weeks long and runs from May to April of the following year (not including two summer months). Students spend these forty weeks in practicum rotations that include private veterinary offices, government offices, working with wildlife veterinarians, working on ranches, and the like.

Other CEL within the faculty include courses with a service-learning component that has included a Northern Community Rotation, a Housing Project, and research in Tanzania. A faculty member said, "We could not deliver this program without that community engagement. We need the community" (PV2, 01.24.2015). 


\section{Haskayne School of Business}

A senior administrator discussed the nuances of CEL at the School: on the one hand, the term CEL is not broadly used or taken up directly; this is not typically the language used to describe the relationship between the School and the wider community. On the other hand, "Haskayne was one of the frontrunners in terms of doing community-engaged learning; we just never called it that. We've always engaged community in a lot of our business courses, where we specifically work with businesses out in the community" (PB1, 01.14.2015).

This administrator also differentiated between the co-op program for business students and CEL. Some examples include Selling Smiles, whereby undergraduate students in a particular Sales Management course gain "real world" selling skills by selling products to raise funds for the Children's Wish Foundation. Sales teams of five students are given a small budget and sample kits and asked to develop and implement an effective sales strategy. At the time of the interview, students had raised more than $\$ 150,000$ for the charity.

There are several course-based examples of CEL in the faculty. For example, an introductory marketing course partners with a local not-for-profit or small business looking for additional help. They have partnered in the past with organizations including Alberta Ballet, Calgary Foothills Soccer league, and local restaurants. Students complete two assignments: first, a research project on the organization and area of work, and second, a marketing plan with recommendations for the client. There are typically 360 students per term in this course. As the instructor reported:

My goal is to make the class both interesting and practical, and students appreciate it. It gets them outside the classroom as well and bringing in those guest speakers it gives them, "Ok, this is actually what I learned and how they're using those ideas." So I think it's useful. (PB2, 01.20.2015)

According to the instructor, CEL is something that many instructors want to do much more. The biggest stumbling block seems to be the perception of a lack of infrastructure and targeted administrative support. The faculty used to have a project office to manage these kinds of projects and facilitate connections between the community and the university. That point of contact no longer exists, but this instructor suggested developing some sort of portal, similar to a "Match.com for matching up community interest and the interests of professors." The instructor described the importance of CEL:

I think it's really valuable. It is definitely something our students want and expect... A key piece, especially before they go out into the workforce, having some experience working, the students say that's the most valuable thing that they've had in their degree, so facilitating that, and offering that to every student. (PB2, 01.20.2015) 
According to the instructor, employers can thereby provide feedback that students feel they need — namely, more "real world" experience. Additionally, working together, working in groups offers opportunities to help develop people skills. This last point was also raised by the senior administrator with whom we spoke; "These are the kinds of projects that really help students think through that, and be able to handle those situations, give them practice dealing with people-issues that they are going to run into (PB1, 01.14.2015).”

\title{
Schulich School of Engineering
}

The Schulich School of Engineering has a relatively broad and expansive definition of CEL. A senior administrator explained that CEL within the faculty includes all forms of student interaction with the external community to the university. This includes curricular and cocurricular experiences, service-learning classes, capstone courses, and paid student internships.

In a first-year design course, students work on projects related to inclusive design related to service-learning offerings. The class partners with local organizations working on a particular social issue. Examples of past partnerships include: local disability organizations to design tools or implements for use in the home to help people with disabilities; designing toys for the local Childrens' Hospital for children with disabilities; working with Engineers Without Borders to find engineering design solutions for communities in the developing world; and projects related to affordable housing and a 10-year plan to end homelessness. In all cases, students conducted research to understand the broader context in which their design project occurs.

This is a required course for all first-year engineering students, and there are between 600 and 800 students in each class. One faculty member emphasized the importance of opening the students' eyes to inequity through their CEL:

\begin{abstract}
A lot of students have not made up their minds on what their engineering career is going to look like... In one of the lectures when we talk about design for development, 95 percent of engineers are designing for 10 percent of the world's population so there's only 5 percent designing for the other 90 percent. That's a big inequity and a lot of students don't realize until you tell them. They become more interested to say, "Hey I can be useful in that other realm and there's lots of opportunity but also lots of room for lending a helping hand." (PE1, 01.14.2015)
\end{abstract}

Further, through internships, Engineering students can spend 12-16 months working with a company in a paid position. Some students work in Calgary while others have travelled further afield to places like Italy or Switzerland. Finally, through a Group Travel Study Program, there are opportunities for students to travel to other countries in small groups to partner with universities overseas and engage in research and study-related activities.

Engineering has struggled to attract a diverse demographic, including women, and there are initiatives now in place to address this. Some administrators believe that having CEL opportunities might attract a more diverse demographic of applicants and, ultimately, 
engineers. According to a senior administrator, there must be institutional and infrastructure support for CEL to flourish:

I'm able to see a lot of different models but the ones that impress me most are well-designed from the perspective of the support and infrastructure, not only infrastructure but human resources as well. Whenever they get external development money there's always a percentage of that that goes to hire people, instead of, "We have the money, now let's find the professor volunteers who are going to do it."... we have to have the proper support to make it as easy as possible for the professors to engage in these activities without being totally consumed... We just need to have that structure. (PE2, 01.20.2015)

\section{Werklund School of Education}

Within the Werklund School of Education, CEL is considered a "signature pedagogy" for undergraduate students. Werklund defines community-based learning as: "a pedagogical model that connects classroom-based work with meaningful community involvement and experiences" (PEd1, 03.14.2015). A senior administrator acknowledged that while the practicum component for pre-service teachers takes place within a community setting, this is distinguished from other forms of CEL. In this sense, the definition is narrower in scope and focuses on community-engagement beyond the practicum component of teacher education.

One long-standing example of a CEL program is a community-initiated service-learning program for undergraduate students developed in 2011 based on the recognized need for improved learning outcomes for children and youth of immigrant families in the local community. Initiated by community and co-founded and led by the lead author, this program seeks to provide undergraduate education students with experiential learning opportunities that will better prepare them for the culturally diverse classroom needs. Each year, about 50 students of the approximately 500 first-year undergraduate students volunteer for the program. Their weekly coursework within a mandatory diversity course includes a social justice framework to understand and reflect critically on their community experiences (Lee \& Lund, 2016; Lund, 2018; Mitchell, 2010).

This unique collaboration initially came from a local immigrant-service agency, which sought solutions to the challenges children and youth of immigrant families faced. Pre-service teachers are placed in a range of community settings to work with children and youth from immigrant families outside of the conventional classroom. This includes after-school programs run by immigrant-serving agencies and other community partners.

In the past few years, the program has transitioned to become a permanent CEL program offered through the Werklund School of Education. It has expanded to include placements in agencies serving LGBTQ+ youth, children and youth with disabilities, Indigenous children and youth, and children and youth of immigrant and refugee backgrounds (Lund \& Lee, 2015). A program administrator explains that: 
We are more than just teachers in a classroom. We are all community members... The better that we can help create conditions where teachers begin to explore those intersectional and overlapping identities, the better we'll be as teachers, and the better off students will be in schools. (PEd2, 03.14.2015)

More recently, the school has expanded its number of service-learning offerings to include several different co-curricular and curricular options for B.Ed. students with agencies in the local community and has hired a full-time facilitator to coordinate the recruitment and placements. Other examples of CEL within the School include a Partner Research Schools program, wherein numerous schools in the area have partnered with the faculty to facilitate collaboration and research between schools, school authorities, communities, and universities. In an optional undergraduate program, Teaching Across Borders, students volunteer to travel abroad during the final year of their B.Ed. program to engage with schools and community services. These are three-month commitments, volunteer-based, and connected to their undergraduate coursework.

\section{University Co-Curricular CEL}

There are numerous co-curricular CEL opportunities for students across campus. Because of this scan's limited scope, we have not attempted to capture a fulsome picture of all these activities. Instead, we have opted to focus on a high-level view of co-curricular CEL. Thus, rather than go faculty by faculty, we spoke to a senior administrator in this area and have included some of the Centre for Community-Engaged Learning (CCEL) work in this section. The administrator defined co-curricular CEL as "learning that takes place outside of the formal environment like a classroom and is embedded within an alternative setting." The intention is that, "these experiences make students more successful in their studies, more engaged students; it really helps them get the most out of their programs here."

Examples of co-curricular CEL include the UCalgaryCares Program, a series of servicelearning opportunities offered through the CCEL. Through this program, undergraduate students from any faculty, department, and year of study can learn about important social issues by working with community organizations in a meaningful way. Students learn, work, travel, and in some cases, live together, locally, nationally, and internationally. All of these opportunities take a systems approach and are rooted in principles of social justice. Students undertake pre-experience workshops and participate in reflective activities, guest speakers, tours, forums, and experiential learning activities; finally, they participate in a debrief session after their return.

The university has an official co-curricular document to recognize a student's out-ofclassroom experiences, and there are a multitude of activities that may be recognized, including student leader roles held in clubs and organizations. Students must complete 20 hours over a year in the activity, and approximately 6000 students per year have a co-curricular record.

Co-curricular CEL opportunities may provide an important entry point for other forms of CEL. For example, students may be cautious about taking a for-credit course with 
a community-engaged component if they do not have experience in this area. An ongoing challenge is in trying to coordinate the placements in a more coherent manner across campus. As the administrator explains, "If you're a community organization and you'd like to work with us, how do you do that? It needs to be more coordinated" (PCC1, 03.15.2015).

\section{Discussion}

Our campus scan is an admittedly limited snapshot of the range and type of communityengaged learning that was being undertaken by faculties across campus at a single Canadian university. Several administrators and leaders of these programs and projects offered their perspectives on this work's nature and the ongoing and emerging needs identified through their varied experiences. The section below outlines seven key findings emerging from this study's results, ranging from definition through practice.

1. Community-engaged learning is defined rather broadly and unevenly. At the outset of this research, it was acknowledged that there was no shared definition of CEL across the university. This was amply confirmed as we collected primary data through interviews across eleven local undergraduate faculties; each faculty has its own vision of what each of these three terms mean: community, engagement, and learning. Others conducting surveys of their campus have found a similar limitation (Cheng et al., 2015). From the data, we generalize that most faculties would agree that CEL is learning that takes place outside of a conventional classroom. That said, "outside the conventional classroom" remains a vast concept. For example, in some of the more extensive service-learning courses, students technically stay in the classroom and "the community" comes in (e.g., as guest speakers, lecturers, collaborators, etc.).

We see that the line between the university community and the wider community is permeable. This is especially true in applied programs - most notably, Veterinary Medicine, Nursing, Education, and Social Work - where much of student learning takes place in community settings. In these programs, the "conventional classroom" can include classrooms in elementary schools, clinical settings in hospitals, veterinary clinics in rural communities, and any number of not-for-profit agencies.

While some faculties consider a practicum experience to be CEL, others differentiate it from other CEL opportunities, like service-learning, as discussed below. Like practica, cooperative programs pose a similar definitional challenge: Some administrators within faculties and schools consider co-op placements as core to a faculty's CEL strategy while some do not. While these divergent perspectives pose a challenge in terms of finding one shared definition, they do reflect the richness and diversity of CEL across the university.

2. Providing meaningful CEL opportunities is labour-intensive. Across each faculty, we heard about the labour-intensive nature of CEL opportunities. In particular, course-based servicelearning opportunities and exception capstone courses require considerable logistical and administrative work. Often, faculty must invest significant time building relationships in the community (Cooper, 2014). They have to support students across a variety of locations.

Engaged Scholar Journal: Community-Engaged Research, Teaching, and Learning 
Further, they have to manage relationships between their students and the wider community and troubleshoot if problems arise. Faculty members taking on these initiatives also take on the regular responsibilities of managing a course: delivering content, providing opportunities for reflection and learning, and marking assignments.

Two specific points emerged with respect to this work: a.) There needs to be administrativel infrastructural support for this work to be sustainable. Across faculties there was a general consensus that there needs to be administrative and infrastructural support in place to facilitate CEL opportunities. Several faculties identified that instructors would be more motivated to provide CEL in their classrooms if there were more support available. For example, this could look like administrative support to assist faculty with the logistics of planning and coordinating the service-learning course. It could also be the establishment of a bank of possible community partners for a particular course. b.) CEL needs to be tied to faculty recognition and evaluation. Following the first point, several faculty members acknowledged that there remains a disconnect between the ways faculty are evaluated and promoted and the emphasis on creating meaningful CEL opportunities. To put it simply, there are few rewards within the academic system of merit and tenure to recognize faculty who provide these kinds of opportunities for their students. Thus, it often falls to faculty who have profound intrinsic motivation and a passion for work in that area. We heard resoundingly that if CEL is to become a greater priority within the university, there need to be systems in place to recognize and value the labour of providing these opportunities for students.

3. CEL is perceived as something that might attract more diverse students. Several faculties identified CEL opportunities as experiences that might attract more diverse students to the faculty. This was especially true in faculties that have historically had a particular gender bias. Administrators in these faculties suggested that providing more opportunities for engagement with the broader community might attract a more diverse applicant base.

4. Professional faculties have divergent perspectives of "what counts" as CEL. As mentioned above, professional practicum placements sit at an exciting intersection of CEL and more conventional learning. Faculties that have a strong professional practicum component had differing perspectives on whether practicum should be included within the definition of CEL. This suggests the need for further discussion on this particular divergence.

Nursing and Education both have large components of their program that involve students working and learning in supervised professional settings (i.e., in schools and hospitals). In both cases, the administrators with whom we spoke differentiated between these experiences and other - more narrowly defined - CEL opportunities. For example, Education focused on specific service-learning opportunities. Nursing focused on one term in the nursing degree program when students work with community partners in non-clinical settings (i.e., not-forprofit organizations, schools, etc.)

In contrast, respondents from the Faculties of Veterinary Medicine and Social Work both identified their "field education" components as core to their CEL strategies. In Veterinary 
Medicine, the service-learning opportunities that exist were considered secondary to the fourth-year community rotations where students spend forty weeks working in "community" settings (i.e., private veterinary clinics, with government, on ranches, and so on). Similarly, the Social Work administrator identified field education as a "signature pedagogy" and core to how the faculty defines its relationship with the broader community.

5. Co-curricular examples should be studied more deeply on a faculty-by-faculty basis. To narrow the scope of this scan, we focused on curricular CEL opportunities on a faculty-byfaculty basis. While we did include a high-level, university-wide perspective, we feel that more research is needed to understand more fully the variety of community-engaged work and learning taking place at a co-curricular level within each faculty. From Medicine to Engineering to Social Work and beyond, there are numerous initiatives, projects, volunteer experiences, and other opportunities that allow students to engage with the community. These are mostly student-run and student-led and can provide transformative learning experiences to students and opportunities for leadership and personal growth.

\section{A central campus office or location should exist for communities to connect with the university.} Faculty and administrators alike identified that there is currently an operational or administrative gap that makes community-engagement challenging: Specifically, there is no central hub for the community to connect with the university and for the university to connect to community; this means that there may be missed opportunities for collaboration and engagement. One administrator suggested an online dating-style site for university-community partnerships to pair university participants with stakeholders in the community. At present, this gap likely acts as a barrier for faculty who would like to engage with the community but are unsure where to begin, as well as for community partners who may be interested in working with the university but are unsure whom to contact.

\section{There is a need to measure and evaluate the collective impact of CEL initiatives, both within} faculties and across the university. One of the questions that we posed to every faculty was whether and how they were measuring the impact of CEL at the faculty level. With few exceptions, the answer to this question was that they were not. Many individual service-learning courses do measure and evaluate the impact of CEL opportunities on student learning. Similarly, many of the co-op programs and field experience placements involve student reflection activities, which is generally seen as a core component of the "learning" in CEL.

However, at a faculty level no one person or office is measuring the collective impact of community-engaged learning within that faculty. In fact, very few faculties are even collecting basic descriptive data on student engagement beyond the traditional classroom. Often, in response to this question, senior administrators responded with comments to the effect of: "We should be doing more." The question of measurement and evaluation gets to the core of the value and role of CEL within faculties and within the university as a whole. Much more work is needed to define and refine measurement tools to assess the impacts of these experiences. 


\section{Conclusions}

The findings discussed above from this relatively limited environmental scan across one university's local undergraduate faculties offer much food for thought. This research was an intentional effort to build on past research about the organizational elements of communityengaged programming (Armitage \& Levac, 2015; Cooper, 2014; De Leon, 2014; Moely \& Ilustre, 2014; O'Meara et al., 2013), and include the views and voices of those administrators tasked with overseeing these programs. Our respondents provide many insights into what is working well in CEL and the potential directions each faculty and the university may follow to strengthen their commitment to, and success in, community-engaged opportunities for students. CEL remains a core part of many universities' strategic plans, and a growing number of faculty and students are involved in various forms of it across most campuses. Reflecting on the potential areas of growth for community-engaged opportunities for their own university, Cheng et al., (2015) concluded that "the ability for engaged scholars and communities to collaborate, to learn from one another, and to co-create knowledge will expand as the academic institutions attempt to better define and provide formal recognition for community-engaged scholarship" (p. 212).

Further research is needed to explore in greater depth the benefits and challenges of CEL from faculty, instructor, student, and community perspectives. Additionally, in recent years, a shift is happening to more critical models that challenge oppression and inequity and move students toward activist stances taken in conjunction with community partners toward social justice (Lund, 2018; Cipolle, 2010; Kajner et al., 2013; Mitchell, 2010; Tinkler et al., 2016). Tinkler and Tinkler (2017) found in their research on pre-service teachers in thoughtfully designed CEL placements that their "practice will be embedded within a community context, and if this context attends to social justice... there is the potential for greater equity for all members of the community" (p. 10). Ongoing difficult questions around equity, ownership, reciprocity, and collaboration in these CEL initiatives remain salient for any post-secondary institution. There is much work to be done to enhance and sustain strong CEL models moving forward.

\section{Acknowledgements}

This research was supported by a Teaching and Learning Experiential Grant from the Taylor Institute of Teaching and Learning at the University of Calgary, but the findings and the views expressed herein are solely those of the authors.

The Conjoint Faculties Research Ethics Board approved this study (Certificate No. REB141391), and participants signed a consent form that absolute confidentiality and anonymity could not be guaranteed. Still, we have taken reasonable steps to obscure the identities of individual participants in the study. 


\section{About the Authors}

Darren E. Lund (corresponding author) is a professor in the Werklund School of Education at the University of Calgary. His research examines social justice activism in schools, communities, and professional education programs. Darren holds a Social Sciences and Humanities Research Council (SSHRC) Insight Grant and won the 2020 IARSLCE Diversity, Equity, \& Inclusion Award from the International Association for Research on Service-Learning and Community Engaged Learning. He is editor of the award-winning The Wiley International Handbook of Service-Learning for Social Justice (2018). Email: dlund@ucalgary.ca

Bronwyn Bragg earned her doctorate degree in human geography at the University of British Columbia. Her research drew on a participatory anti-oppression framework to explore questions of inclusion and belonging for immigrants and refugees in Canadian cities. Bronwyn has extensive experience working as a community-based researcher. She is currently a SSHRC Postdoctoral Scholar at York University.

\section{References}

Abdul-Raheem, J. (2018). Cultural humility in nursing education. Journal of Cultural Diversity, 25(2), 66-73.

Armitage, T., \& Levac, L. (2015). Learning the development of community-engaged scholars through course-based learning: A student perspective. Engaged Scholar Journal: Community-Engaged Research, Teaching, and Learning, 1(1), 148-163. https://doi.org/10.15402/esj.v1i1.25

Bragg, B., \& Lund, D. E. (2015, June). Community-engaged learning scan: University of Calgary [Final research report]. Werklund School of Education \& Centre for Community-Engaged Learning.

Butin, D. W. (2010). Service-learning in theory and practice: The future of community engagement in higher education. Palgrave McMillan.

Cheng, J., Muhajarine, N., McMullen, L., \& Dunlop, A. (2015). Measuring capacity for communityengaged scholarship: Results from an institutional self-assessment at the University of Saskatchewan. Engaged Scholar Journal, 1(2), 197-214. https://doi.org/10.15402/esj.v1i2.108

Cooper, J. R. (2014). Ten years in the trenches: Faculty perspectives on sustaining service-learning. Journal of Experiential Education, 37(4), 415-428. https://doi. org/10.1177/1053825913513721

Creswell, J. W. (2013). Qualitative inquiry and research design: Choosing among five approaches (3rd ed.). Sage.

De Leon, N. (2014). Developing intercultural competence by participating in intensive intercultural service-learning. Michigan Journal of Community Service Learning, 21(1), 17-30. 
Hatcher, J. A., \& Bringle, R. G. (Eds.). (2012). Understanding service-learning and community engagement: Crossing boundaries through research. Information Age.

Kajner, T., Chovanec, D., Underwood, M., \& Mian, A. (2013). Critical community service-learning: Combining critical classroom pedagogy with activist community placements. Michigan Journal of Community Service Learning, 19(2), 36-48.

Lee, L., \& Lund, D. E. (2016). Infusing service-learning with social justice through cultural humility. In A. S. Tinkler, B. E. Tinkler, J. R. Strait, \& V. M. Jagla (Eds.), Service-learning to advance social justice in a time of radical inequality (pp. 359-381). Information Age.

Lund, D. E. (Ed.). (2018). The Wiley international handbook of service-learning for social justice. WileyBlackwell.

Lund, D. E., \& Lee, L. (2015). Fostering cultural humility among pre-service teachers: Connecting with children and youth of immigrant families through service-learning. Canadian Journal of Education, 38(2), 1-30. Retrieved from http://www.cje-rce.ca/index.php/cje-rce/article/ view/1744/1756

Mitchell, T. D. (2010). Challenges and possibilities: Linking social justice and service-learning. Michigan Journal of Community Service Learning, 17(1), 94-97.

Moely, B., \& Ilustre, V. (2014). The impact of Service-learning course characteristics on university students' learning outcomes. Michigan Journal of Community Service Learning, 21(1), 5-16.

National Survey of Student Engagement. (2013). NSSE Research brief: Promoting high-impact practices: Maximizing educational gains. Bloomington, IN: Indiana University Center for Postsecondary Research. Retrieved from http://nsse.indiana.edu/pdf/HIP_brief_final.pdf

Northern Illinois University. (2012). Instructional guide for university faculty and teaching assistants: Experiential learning. Northern Illinois University, Center for Innovative Teaching and Learning. https://www.niu.edu/citl/resources/guides/instructional-guide

O’Meara, K., Lounder, A., \& Hodges, A. (2013). University leaders' use of episodic power to support faculty community engagement. Michigan Journal of Community Service Learning, 19(1), $5-20$.

Przednowek, A., Goemans, M., \& Wilson, A. (2018). “I had a big revelation”: Student experiences in community-first community-campus engagement. Engaged Scholar Journal, 4(2), 21-41. https://doi.org/10.15402/esj.v4i2.61746

Tinkler, A. S., \& Tinkler, B. E. (2017). Community conversations shape reciprocal partnerships for social justice: A case study of a comprehensive service-learning initiative in a teacher education program. International Journal of Research on Service-Learning in Teacher Education, $5,1-12$.

Tinkler, A. S., Tinkler, B. E., Strait, J. R., \& Jagla, V. M. (Eds.). (2016). Service-learning to advance social justice in a time of radical inequality. Information Age.

University of Calgary. (2011). Eyes high strategic direction. Calgary, AB: University of Calgary. Retrieved from https://issuu.com/devoff/docs/eyes_high 